Pesq. Vet. Bras. 35(1):6-8, janeiro 2015

DOI: $10.1590 / \mathrm{S} 0100-736 \mathrm{X} 2015000100002$

\title{
First isolation and characterization of Leptospira interrogans serogroup Australis from swine in Brazil ${ }^{1}$
}

\author{
Camila Hamond ${ }^{2}$, Gabriel Martins ${ }^{2}$, Ana Paula Loureiro² ${ }^{2}$, Sylvie Bremont ${ }^{3}$, Marco \\ Alberto Medeiros ${ }^{4}$, Pascale Bourhy ${ }^{3}$ and Walter Lilenbaum ${ }^{2 *}$
}

\begin{abstract}
Hamond C., Martins G., Loureiro A.P., Bremont S., Medeiros M.A., Bourhy P. \& Lilenbaum W. 2015. First isolation and characterization of Leptospira interrogans serogroup Australis from swine in Brazil. Pesquisa Veterinária Brasileira 35(1):6-8. Laboratório de Bacteriologia Veterinária, Instituto Biomédico, Universidade Federal Fluminense, Rua Hernani de Melo 101, Niteroi, RJ 24210-030, Brazil. E-mail: mipwalt@vm.uff.br

The purpose of this study was to report the first recovery and characterization of Leptospira interrogans (serogroup Australis) from urine of swine in Brazil. The isolate was studied by serogrouping, MLVA, PGFE, and partial sequencing of $r r s$ and $\sec Y$. It was serogrouped as serogroup Australis, probably serovar Bratislava (titre 1,600), and sequenced as Leptospira interrogans. The MLVA and PGFE profiles also suggested the isolate as serovar Bratislava, since they were indistinguishable from reference strains Balico and Jez Bratislava. This is the first Leptospira interrogans serogroup Australis isolate, probably serovar Bratislava, obtained in Brazil.
\end{abstract}

INDEX TERMS: Leptospira interrogans, Australis, swine, Brazil.

RESUMO.- [Primeiro isolamento e caracterização da Leptospira interrogans sorogrupo Australis de suíno no Brasil.] 0 objetivo deste estudo foi relatar o primeiro isolamento e caracterização de Leptospira interrogans (sorogrupo Australis) a partir da urina de suínos no Brasil. 0 isolado foi caracterizado por sorogrupagem, MLVA, PGFE, e sequenciamento parcial de rrs e secY. Este foi identificado como pertencente ao sorogurpo Australis, provavelmente sorovar Bratislava (título 1600) e sequenciado como Leptospira interrogans. Os perfis de MLVA e PGFE também sugeriram o isolado como sorovar Bratislava, uma vez que estes foram indistinguíveis das cepas de referência Balico e Jez Bratislva. Este é o primeiro isolado de Leptospira interrogans sorogrupo Australis, provavelmente sorovar Bratislava, obtido no Brasil.

TERMOS DE INDEXAÇÃO: Leptospira interrogans, Australis, suíno, Brasil.

\footnotetext{
${ }^{1}$ Received on August 14, 2014.

Accepted for publication on December 12, 2014.

${ }^{2}$ Laboratório de Bacteriologia Veterinária, Instituto Biomédico, Universidade Federal Fluminense (UFF), Rua Hernani de Melo 101, Niteroi, RJ 24210-030, Brazil. *Corresponding author: mipwalt@vm.uff.br

${ }^{3}$ Institut Pasteur, Unité de Biologie des Spirochètes, National Reference Center, Paris, France.

${ }^{4}$ Laboratório de Tecnologia Recombinante, Bio-Manguinho-Fiocruz, Av. Brasil 4365, Maguinhos, Rio de Janeiro, RJ 21045-900.
}

\section{INTRODUCTION}

Leptospirosis is an important infectious disease in livestock determined by spirochetes belonging to the genus Leptospira sp., which is reported worldwide, particularly in tropical countries (Martins \& Lilenbaum 2013).

The clinical signs of leptospirosis in swine vary according to the infecting serovar (sv). While serovars as Grippotyphosa or Icterohaemorrhagiae may cause severe disease and are associated with high titers of antibody and short renal carrier state, infection by members of serogroup Australis, particularly sv Bratislava, is characterized by a low serologic response, rapid transmission from pig to pig, mild clinical signs, reproductive failure and a prolonged renal carrier state (Ellis et al. 1986). Pigs are generally considered as the reservoir host species for the serovars Pomona, Bratislava and Tarassovi (Strutzberg-Minder \& Kreienbrock 2011). Clinical signs of leptospirosis in pigs include abortion, weak or stillborn piglets, which can affect the productivity and profitability of the herd (Faine et al. 2000). Serological evidence of the serogroup Australis occurrence, particularly sv. Bratislava in Brazil has already been reported in horses, pigs, dogs, cattle and small ruminants (Oliveira et al. 2001, Lilenbaum et al. 2007, Soto et al. 2007, Lavinsky et al. 2012, Martins \& Lilenbaum 2013). Nevertheless, the only available report regarding serogroup Australis isolation in national territory refers 
to a L. noguchii strain named Hook, which was obtained from a clinical diseased dog in Southern Brazil (Silva et al. 2009). Isolation of local strains is required for a definitive epidemiological understanding of their real occurrence. Therefore, this study presented the first report of Leptospira interrogans serogroup Australis recovery from swine urine in Brazil.

\section{MATERIALS AND METHODS}

Fifteen swine (13 females and 2 males, 2 to 9 years old) from the same herd located in Rio de Janeiro, Brazil, without reproductive problems and unvaccinated/untreated for leptospirosis were studied. From all animals, blood was collected for serology (Microscopic Agglutination Test - MAT) and urine samples were collected for bacteriological culturing and PCR.

For anti-Leptospira antibodies detection, MAT was conducted with a complete panel, which included 28 serovars representing 24 serogroups (Institute Pasteur - Paris, France), following the international standards (Faine et al. 2000). Infective serogroup (serovar) was considered to be that one which presented the highest titre. Sera presenting titers $\geq 100$ were considered reactive, while those ones with titers $\geq 800$ were considered strongly reactive, denoting an indication of acute infection (Martins \& Lilenbaum 2013).

Immediately after collection (spontaneous urination), few drops of urine samples were inoculated into tubes containing $5 \mathrm{~mL}$ of EMJH liquid media (Difco Laboratories, USA) and $5 \mathrm{~mL}$ semisolid Fletcher media (Difco, USA). At the laboratory, tubes were incubated at $28 \stackrel{\circ}{\circ}$ and examined under darkfield microscopy weekly during 20 weeks (Faine et al. 2000).

For urine PCR, DNA was extracted using Promega Wizard SV Genomic DNA Purification System ${ }^{\circledR}$ (Promega, Madison, USA). PCRs were conducted targeting the lipL32 (outer membrane lipoprotein LipL32) with primers LipL32-45F (5'-AAG CAT TAC CGCTTG TGG TG-3') and LipL32-286R (5'-GAA CTC CCA TTT CAG CGA TT- 3'), using the recently described protocol (Hamond et al. 2014).

The obtained isolate was serogrouped using a panel of 32 specific antisera provided by Royal Tropical Institute (KIT, Amsterdam) and following Faine et al. (2000) recommendations. Furthermore, its DNA was extracted and partial sequencing of the rrs (16s rRNA) and secY (pre-protein translocase SecY protein) was proceeded employing the primers $\mathrm{F}\left(5^{\prime}\right.$-ATGCCGATCATTTTTGCTTC-3') and R (5'-CGTCCCTTAATTTTAGACTTCTTC-3') (Ahmed et al. 2006), and LA (5'-GGCGGCGCGTCTTAAACATG-3') and LB (5'-TTCCCCCATTGAGCAAGATT-3') (Merien et al. 1992). Sequencing was performed at the Genotyping of Pathogens and Public Health Platform (Institut Pasteur, Paris, France). All molecular epidemiological data were stored and analyzed with Bionumerics software (Version 6.5; Applied-Maths, Belgium). Genotyping was also performed by multiple-locus variable-number tandem repeat analysis (MLVA) using the loci VNTR4, VNTR7, and VNTR10 as described by Salaün et al. (2003). Based on the partial sequencing of gene $\sec Y$, PFGE was conducted using Not I restriction enzyme (Herrmann et al. 1992), in order to compare the DNA of the isolate with reference strains of same species and serogroup, such as Australis Balico and Jez Bratislava.

\section{RESULTS AND DISCUSSION}

Nine out of the fifteen (60\%) tested sera were reactive, five of them against serogroup Australis (sv. Bratislava) with titres of 400. Four were reactive against serogroup Icterohaemorrhagiae (sv. Copenhageni) with titres of 100. PCR was able to detect leptospiral DNA in the urine of 7/15 (46.7 $\%$ ) swine, being four seroreactive and three seronegative. One urine sample, from a 4 year-old male, yielded pure culture of leptospires, named SU5 (GenBank KP263059).

SU5 was serogrouped as Australis (titre 1,600), and partial sequencing of $\sec Y$ and $r r s$ genes characterized it as Leptospira interrogans genomospecies. Based on $\sec Y$ nucleotide sequences (Fig. 1), this isolate showed similarity to reference strain Balico (sv Australis) isolated from humans in Australia, and to reference strain Jez_Bratislava (sv Bratislava), isolated from a hedgehog in Slovakia, as well as to strain 200801323 (sv Bratislava) isolated from human in Martinique. Furthermore, both MLVA and PFGE techniques grouped SU5, Balico and Jez-Bratislava strains in the same profile, demonstrating the close relationship among them. One limitation of the molecular methods compared to the serological ones should be highlighted; even though the cross agglutination absorption test (CAAT) is complex, laborious and expensive, the genetic techniques do not allow to reliably classify strains to a serovar level, particularly when it becomes necessary to differentiate between serovars closely related, as Australis and Bratislava. It must be considered, however, that in the present study the highest titres were obtained against Bratislava reference strain $(1,600)$, while for the other tested members of serogroup Australis, the titre was never higher than 800 . Thus, the association of agglutination tests with molecular analysis allowed to suggest that the SU5 strain is a $L$. interrogans member of serogroup Australis, probably serovar Bratislava. And this finding agrees to the available seroepidemiological data regarding animal leptospirosis in the studied region, which refer Bratislava as a common serovar on Brazilian serological surveys (Oliveira et al. 2001, Lilenbaum et al. 2007, Soto et al. 2007, Lavinsky et al. 2012, Martins \& Lilenbaum 2013). Moreover, Bratislava has been associated with subfertility and litter size reduction (Boqvist et al. 2002). In this particular case, the absence of clinical signs of leptospirosis observed in

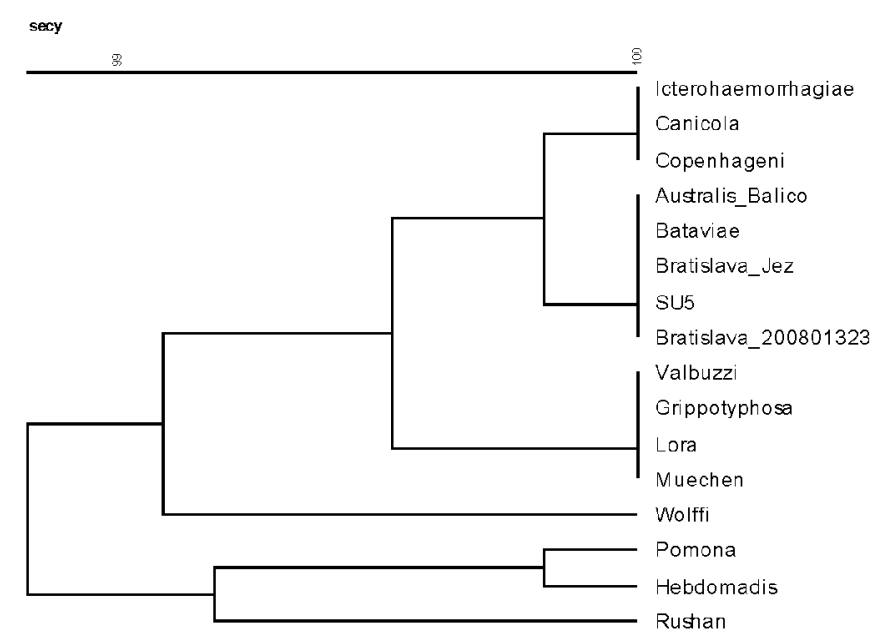

Fig.1. Phylogenetic tree based on partial sequencing of $\sec Y$. 
the studied herd corroborates this hypothesis.

\section{CONCLUSION}

This is the first report of serogroup Australis recovery from swine in Brazil, and confirms the circulation of strains of this serogroup in the region, pointing out to new epidemiological perspectives of animal leptospirosis in the country.

Acknowledgements.- This study was supported by FAPERJ, CNPq and CAPES. W. Lilenbaum and M.A. Medeiros are CNPq fellows.

\section{REFERENCES}

Ahmed N., Devi S.M., Valverde M.L., Vijayachari P., Machang'u R.S., Ellis W.A. \& Hartskeerl R.A. 2006. Multilocus sequence typing method for identification and genotypic classification of pathogenic Leptospira species. Ann. Clin. Microbiol. Antimicrob. 23:28-44.

Boqvist S., Thu H.T.V., Vagsholm I. \& Magnusson U. 2002. The impact of Leptospira seropositivity on reproductive performance in sows in southern Viet Nam. Theriogenology 58:1327-35.

Ellis W.A., McParland P.J., Bryson D.G. \& Cassells J.A. 1986. Prevalence of Leptospira infection in aborted pigs in Northern Ireland. Vet. Rec. 118:63-65.

Faine S., Adler B., Bolin C. \& Perolat P. 2000. Leptospira and Leptospirosis. Medisci, Melbourne.

Hamond C., Pinna A., Martins G. \& Lilenbaum W. 2014. The role of leptospirosis in reproductive disorders in horses. Trop. Anim. Health Prod. 46:1-10.

Herrmann J.L., Bellenger E., Perolat P., Baranton G. \& Saint Girons I. 1992. Pulsed-field gel electrophoresis of NotI digests of leptospiral DNA: a new rapid method of serovar identification. J. Clin. Microbiol. 30:1696-1702.
Lavinsky M.O., Said R.A., Strenzel G.M. \& Langoni H. 2012. Seroprevalence of anti-Leptospira spp. antibodies in dogs in Bahia, Brazil. Prev. Vet. Med. 106:79-84.

Lilenbaum W., de Souza G.N., Ristow P., Moreira M.C., Fráguas S., Cardoso V.S. \& Oelemann W.M. 2007. A serological study on Brucella abortus, caprine arthritis-encephalitis virus and Leptospira in dairy goats in Rio de Janeiro, Brazil. Vet. J. 173:408-412.

Martins G. \& Lilenbaum W. 2013. The panorama of animal leptospirosis in Rio de Janeiro, Brazil, regarding the seroepidemiology of the infection in tropical regions. BMC Vet. Res. 9:237.

Merien F., Amouriaux P., Perolat P., Baranton G. \& Saint Girons I. 1992. Polymerase chain reaction for detection of Leptospira spp. in clinical samples. J. Clin. Microbiol. 30:2219-2224.

Oliveira A.A., Mota R.A., Pereira G.C., Langoni H., Souza M.I., Navegantes W.A. \& Sá M.E. 2001. Seroprevalence of bovine leptospirosis in Garanhuns Municipal District, Pernambuco State, Brazil. Onderstepoort J. Vet. Res. 68:275-279.

Salaün L., Mérien F., Gurianova S., Baranton G. \& Picardeau M. 2006. Application of multilocus variable-number tandem-repeat analysis for molecular typing of the agent of leptospirosis. J. Clin. Microbiol. 44:39543962.

Silva E.F., Cerqueira G.M., Seyffert N., Seixas F.K., Hartwig D.D., Athanazio D.A., Pinto L.S., Queiroz A., Ko A.I., Brod C.S. \& Dellagostin A.O. 2009. Leptospira noguchii and human and animal leptospirosis, Southern Brazil. Emerg. Infect. Dis. 15:621-623.

Soto F.R.M., Vasconcellos S.A., Pinheiro S.R., Bernarsi F. \& Camargo S.R. 2007. Leptospirose suína. Arq. Inst. Biol., São Paulo, 74:379-395.

Strutzberg-Minder, K.S. \& Kreienbrock, L. 2011. Leptospireninfektionen beim schwein: epidemiologie, diagnostik und weltweites vorkommen. Berl. Munch. Tierarztl. 124:345-359. 